\title{
PERFORMANCE MEASUREMENT TOOLS FOR TOTAL QUALITY MANAGEMENT IN APPLICATION TO HEALTHCARE ENVIRONMENT: A QUALITATIVE SYSTEMATIC REVIEW
}

\author{
DANA GROSSU \\ HENRIJS KAL,KIS
}

\begin{abstract}
In the context of rapidly changing business environment, total quality management (TQM) has become a common approach for overall organisational management with the strong emphasis on continuously improving the quality of processes and its outcomes. Hospitals and other healthcare organisations across the globe have been progressively implementing TQM to reduce costs, improve efficiency and provide high quality patient care. Moreover, TQM has become an important part of healthcare organisations' competitive strategy in quality for healthcare delivery. The aim of the research is to identify the most commonly used measurement tools for TQM in application to healthcare environment using comprehensive review of TQM literature. Guided data search and screening process are conducted using qualitative systematic review, and the results identified and interpreted using a quantitative content analysis method of the research. The search of literature was conducted using 4 academic online databases - EBSCO, SCOPUS, MEDLINE, and WEB of SCIENCE. A total of 234 articles were initially searched, full texts of 32 articles were assessed, and 6 articles that met the inclusion criteria were finally included in the research. As the result of systematic article review, the following information has been synthesised: Benchmarking and ISO Standards, Competitive Benchmarking, Management and Employee Self-Developed Questionnaire, Customer Satisfaction Survey, Quality Award Self-Assessment.
\end{abstract}

Keywords: total quality management, healthcare, organizations, performance, measurement tools

JEL code: M10

\section{INTRODUCTION}

In its broad meaning, TQM is directing (managing) the whole (total) production process to produce an excellent (quality) product or service (Helms, 2006).

Øvretveit defines TQM as organisation wide management philosophy for continuously improving the quality of products/services and its processes. 
Continuously quality improvement is the responsibility of everyone who is involved in the production or use of the products or services offered and hence is interested in its quality (Øvretveit (2014). Total quality management in European healthcare).

Furthermore, TQM application to the health care ( $\mathrm{HC})$ environment is the provision of the best possible care through continuously improving service to meet or exceed the needs and expectations of the customer. The customer in the health care environment could be the patient, staff, physician and community serviced by the $\mathrm{HC}$ organisation.

Thus, there are three dimensions of quality in healthcare: Patient quality, Professional quality, Management quality (Øvretveit (2014). Total quality management in European healthcare).

Moreover, one can distinguish eight main principles of TQM. Those principles are: (1) Customer-focused; (2) Total employee involvement; (3) Process-cantered; (4) Integrated system; (5) Strategic and systematic approach; (6) Continual improvement; (7) Fact-based decision making; (8) Communications (Westcott, 2013). Those principles are core values on which organisation is to operate regardless of the field of activities.

Deming and Juran observed that quality involves planning and administration the activities necessary to achieve a high level of performance in a process and identifying opportunities for improving quality and customer satisfaction (Wood, 2005). In this respect it is essentially to elaborate performance measurement tools for determining the results that have been reached and the gaps between the desired outcomes and real situation.

Thus, the aim of the research is to identify the most commonly used measurement tools for TQM in application to healthcare environment using comprehensive review of TQM literature.

\section{METHODS}

The research is conducted using two methodological guidelines: (1) qualitative systematic review for data collection that meet the criteria set (Simon \& Fielding, 2006) and (2) a qualitative content analysis (Elo \& Kyngas, 2008) to identify the finding and interpret the results of the research. The qualitative systematic review was conducted to provide broadened understanding of a particular phenomenon of interest by combining or comparing the finding from many qualitative studies (Simon \& Fielding, 2006). A qualitative content analysis provided the detailed understanding of the measurement tools for TQM evaluation that could be applied to healthcare sector.

The review process consists of the following steps: (1) developing search strategy, (2) developing criteria for inclusion and exclusion, (3) selection of articles, and finally (4) data extraction and data analysis. 


\section{SeArch Strategy}

A systematic search of literature was guided through academic online databases: EBSCO, MEDLINE, SCOPUS, and WEB of SCIENCE (Figure 1). The following search terms were included: (1) "total quality management", "quality management", "quality" (2) "healthcare", "healthcare organizations", "healthcare institutions", "healthcare sector" (3) "measurement tools", "assessment tools", "evaluation".

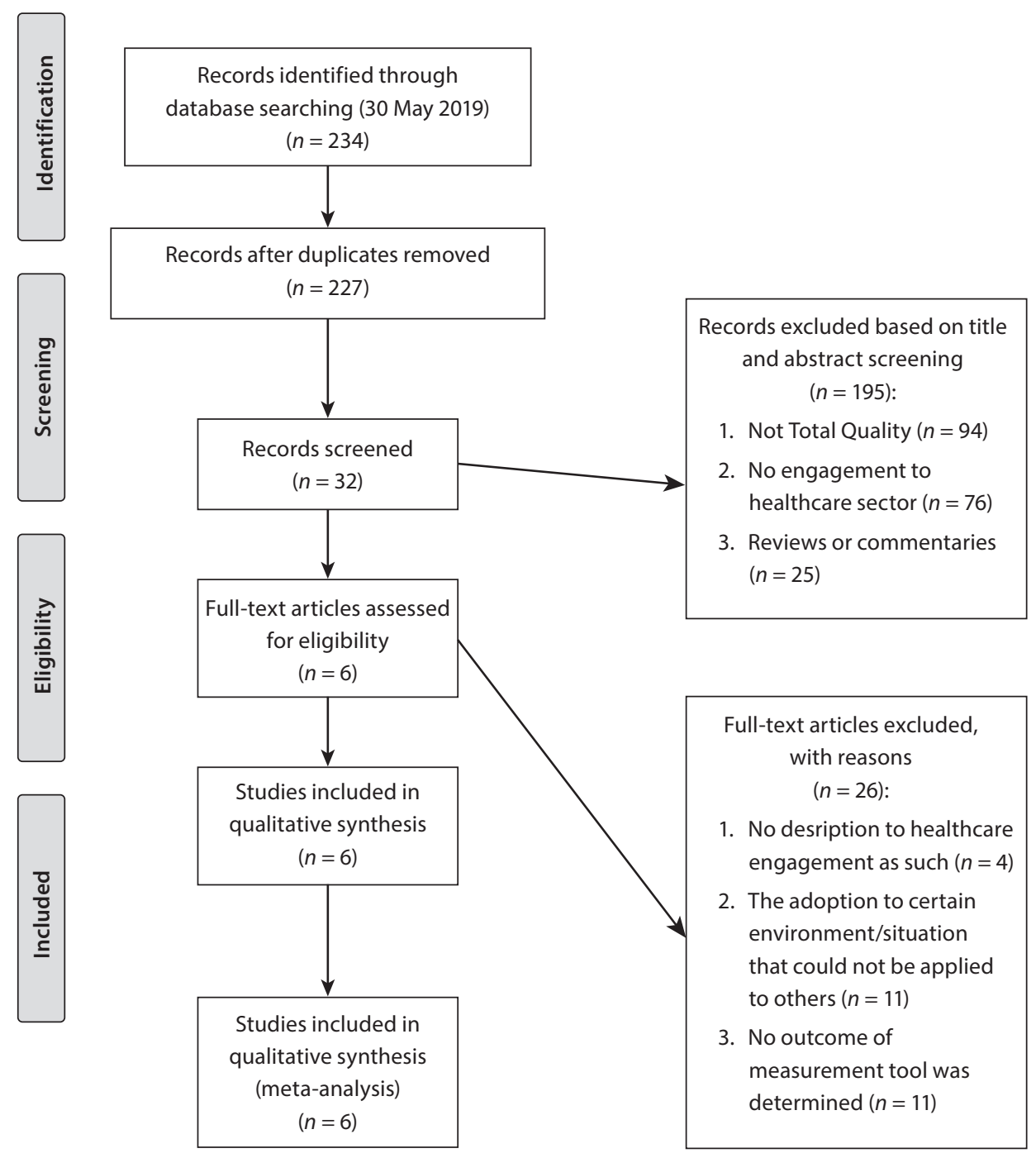

Source: developed by authors

Fig. 1. Search Flow Chart 


\section{CRITERIA FOR INCLUSION}

The following criteria have been set to include articles in the research: (1) actual TQM performance evaluation/measurement/assessment tool has been described; (2) implementation to healthcare sector or environment; (3) published in English in peer-reviewed journals between January 1, 1997, and May 21, 2016.

\section{Criteria For ExClusion}

The following criteria has been set to exclude articles for the research: (1) reviews, commentaries, editorials; (2) dissertations, as there are no peerreviewed publications; (3) articles that described benefits, dimensions, concept, and principles, rather than actual measurement tools for TQ; (3) articles that reported implementation strategies rather than evaluation or measurement tools for TQM.

\section{Selection of Articles}

After the initial search, the authors used bibliographic program RefWorks 1.0.0.1 NVivo 12.0 to identify all eligible articles. Then the authors excluded irrelevant titles and abstracts. Finally, the titles and abstracts that were potentially identified as eligible for inclusion were screened, and full texts were included into research.

\section{Data Extraction and Analysis}

Following qualitative content analysis (Elo \& Kyngas, 2008), the data was managed through open coding and category creation. The primary categories related to research were used as labels, and terms in each article were coded. Categories that were developed during open coding were grouped into similar codes and created headings and making groupings in accordance to TQM dimensions. Further, all eligible articles were imported into NVivo qualitative data analysis program to code texts.

\section{RESULTS AND DISCUSSION}

A total of 234 articles were initially searched, full texts of 32 articles were assessed, and 6 articles that met the inclusion criteria were finally included in the research. As the result of systematic article review, the following information has been synthesised: Benchmarking and ISO Standards, Competitive Benchmarking, Management and Employee Self-Developed Questionnaire, Customer Satisfaction Survey, Quality Award Self-Assessment. 


\section{BENCHMARKING AND ISO STANDARDS}

ISO or International Organization for Standardization has developed a set of standards for healthcare, wellbeing and safety. ISO offers solutions that support the full spectrum of services needed throughout a person's life - from medical devices to health organisation management, to health informatics and traditional medicines (ISO, 2019). Healthcare organisation benchmarking to ISO standards has been identified as one of the measurement tools for TQM system within the organisation $(n=1)$ (Dodrajka, 2007). The authors assume that a company's benchmarking and further adoption to ISO standards (like ISO: 9000) is essential as it indicates the level of quality which customer expects.

\section{Competitive Benchmarking}

As a component of total quality management, benchmarking is a continuous process by which an organisation can measure and compare its own processes with those of organisations that are leaders in a particular area (Benson, 1994). The benchmarking theory is built upon performance comparison, gap identification and changes in the management process (Kay, 2007). The following authors have clearly reported the competitive benchmarking $(n=2)$ : Dodrajka, 2007, and Kay, 2007. The authors indicate that competitive benchmarking is used at the strategic level and determines the standards for organisations performance against corporate priorities, such as customer satisfaction, employee motivation, market share, and return on sales.

\section{Management or Employee Self-Developed QUESTIONNAIRE}

Another instrument for measuring performance of TQM within the organisation is self-developed and self-administered questionnaire, which is conducted with management staff and employees, for example, doctors and medical staff. The researchers suggest using questionnaire which is developed as the synthesis of information during the research, and then adjusted to the environment in which company is operating $(n=3)$ (Talib et al., 2012, Joseph et al., 1997, Salisu et al., 2016). Furthermore, such questionnaire identifies critical factors of TQM in relevant industry/environment and provides holistic framework for TQM improvement.

\section{Customer Satisfaction Survey}

Furthermore, as TQM adopts the principles of customer (or patient) oriented philosophy of management, the customer satisfaction survey is a powerful tool for measuring the performance of TQM within the company $(n=2)$ (Andrzejewski, 1997, Salisu et al., 2016). 
Taking into account that the TQM organisations perceive customers as partners, the decisions are made based on the customer expectations and the level of satisfaction. Moreover, it is vital to follow up the customers in order to respond fast enough to new customer needs and to make sure that the resources are used as effectively as possible to provide customer satisfaction.

\section{Quality Award Self-Assessment}

The authors distinguish three types of self-assessment frameworks: (1) The Malcolm Baldrige National Quality Award (MBNQA), (2) The Deming Prize, (3) The European Quality Award (Aly, 1997).

MBNQA is an award established by the U.S. Congress in 1987 to raise awareness of quality management and recognise U.S. companies that have implemented successful quality management systems. The award is the nation's highest presidential honour for performance excellence within US-based companies (MBNQA homepage asq.org).

\section{THE DEMING PRIZE}

The Prize recognises significant achievements of distinction that have improved performance of an organisation through the application of companywide quality control strategies. The prestige associated with the award is widely believed to have influenced Western thinking of the subject (Kanji et al., 1992).

\section{THE EUROPEAN QUALITY AWARD}

The European Foundation for Quality Management (EFQM) was established to institute and administer the EQA. The principle objectives of EFQM are similar to MBNQA and are illustrated in the model which includes the "enablers" and the "results".

The literature review shows that the main purpose of self-assessment is to:

- Identify strengths in key processes;

- Exploit potential areas of improvement;

- Work on areas which need improvement;

- Monitor the impact of appropriate action plans on regular basis.

The research article focuses on self-assessment of the organisation based on the Quality Award catalogue. The authors suggest that self-assessment is essentially a tool for helping organisations in a variety of ways, including for instance the opportunity to take a broader view on how TQM is impacting on various business operations, as well as the performance measurement of processes (Aly, 1997). 
Summary of the Findings

\begin{tabular}{|c|c|c|c|}
\hline Author & $\begin{array}{c}\text { TQM Measure- } \\
\text { ment Tool }\end{array}$ & Evaluation Focus/Purpose & \begin{tabular}{|l|} 
TQM Dimension in \\
Healthcare (quality)
\end{tabular} \\
\hline Dodrajka, 2013 & $\begin{array}{l}\text { Benchmarking } \\
\text { and ISO } \\
\text { Standard }\end{array}$ & $\begin{array}{l}\text { Internal process evaluation, } \\
\text { potential areas for improvement, } \\
\text { evaluate performance against best } \\
\text { practice }\end{array}$ & $\begin{array}{l}\text { Patient } \\
\text { Management } \\
\text { Professional }\end{array}$ \\
\hline $\begin{array}{l}\text { Dodrajka, } 2007 \\
\text { J. FL. Kay, } 2007\end{array}$ & $\begin{array}{l}\text { Competitive } \\
\text { Benchmarking }\end{array}$ & $\begin{array}{l}\text { External and internal process } \\
\text { evaluation, potential areas } \\
\text { for improvement, measuring } \\
\text { performance of processes, } \\
\text { evaluate performance against best } \\
\text { practices }\end{array}$ & $\begin{array}{l}\text { Patient } \\
\text { Management } \\
\text { Professional }\end{array}$ \\
\hline $\begin{array}{l}\text { Talib et al., } 2012 \\
\text { Joseph et al., } 1999 \\
\text { Salisu et al., } 2016\end{array}$ & $\begin{array}{l}\text { Management } \\
\text { or Employee } \\
\text { Self-Developed } \\
\text { Questionnaire }\end{array}$ & $\begin{array}{l}\text { Internal process evaluation, } \\
\text { identify strengths in key } \\
\text { processes, identify room for } \\
\text { improvement, impact of TQM on } \\
\text { various business operations }\end{array}$ & Management \\
\hline $\begin{array}{l}\text { Andrzejewski, } \\
\text { 1997, } \\
\text { Salisu et al., } 2016 \\
\end{array}$ & $\begin{array}{l}\text { Customer } \\
\text { Satisfaction } \\
\text { Survey }\end{array}$ & $\begin{array}{l}\text { External evaluation, identify } \\
\text { strengths in key processes, } \\
\text { potential areas for improvement }\end{array}$ & Patient \\
\hline Aly, 1997 & $\begin{array}{l}\text { Quality } \\
\text { Award Self- } \\
\text { Assessment }\end{array}$ & $\begin{array}{l}\text { Formative process evaluation, } \\
\text { financial and non-financial } \\
\text { benefits, comparison "like to like", } \\
\text { evaluate performance against } \\
\text { excellence model, impact of TQM } \\
\text { on various business operations, } \\
\text { potential areas for improvement }\end{array}$ & $\begin{array}{l}\text { Patient } \\
\text { Management } \\
\text { Professional }\end{array}$ \\
\hline
\end{tabular}

Source: developed by authors

Table 1 summarises the findings of the research. Following the aim of the research, five commonly used measurement tools for TQM in application to healthcare environment have been identified: benchmarking and ISO standards, competitive benchmarking, management or/and employee self-developed questionnaire, customer satisfaction survey, and finally quality award selfassessment. It has also been determined that TQM measurement tools may differ in its evaluation focus and purpose, though some of the aspects may be common for each tool. Moreover, the tools determined may also vary in respect to its dimension if applied to TQM concept: patient, management or professional.

\section{CONCLUSION}

The modern healthcare service is being encouraged to ensure uniform provision of high-quality healthcare. Therefore, to achieve quality excellence, an organisation should initiate a continuous improvement program using TQM 
as a vehicle of growth and development. The crucial point of TQM system operating within the company is the measurement tools to identify the extent of TQM within the company, as well as potential areas of improvement.

From the practical point of view, the findings of this article provide healthcare management with description of measurement tools to understand TQM practice better and to develop models that are best applicable to certain organisation within specific industry profile.

Researchers or practitioners can use this study to conduct similar research in specific industry; compare and contrast the extent of TQM practice in different industry populations; develop and test the instrument for measurement of TQM across various industry populations.

\section{REFERENCES}

Aly, M. A. (1997). Is Self-Assessment (as a Powerful Tool for Total Quality Management Implementation) Suitable in the Middle East Context? The Experience of a Petrochemical Global Company. Total Quality Management Journal, Vol. 8.

Andrzejewski, N. (2017). Use of a customer satisfaction survey by health care regulators: a tool for total quality management. Public Health Reports (Washington D.C.)

Dodrajka, S. (2007). Total Quality Management and Benchmarking. SAGE Journals.

Elo, S., Kyngas, H. (2008). The qualitative content analysis process. Journal of Advanced Nursing.

Helms, M. M. (2006). Encyclopaedia of Management. New York: Thomson Gale.

Joseph, I. N., Rajendran, C., Kamalanabhan, T. J. (1999). An Instrument for Measuring Total Quality Management Implementation in Manufacturing-Based Business Units in India. International Journal of Production Research, 32(10), 2201-2215.

Kay, FL. J. (2007). Health Care Benchmarking. Medical Bulletin Journal, Vol. 12.

Øvretveit, J. (2014). Evaluating Improvement and Implementation for Health. Berkshire: Open University Press.

Pant, R., Chavan, S. (2018). A Review of Literature and Identification of Total Quality Management Tools for Production Development and Design Integration. International Journal of Mechanical and Production.

Salisu, B., Abbaspour, B., Nodeh, F. M. (2016). Critical Success Factors and Tools for Working the Total Quality Management Revolutions in Management Practice: A Review. Indian Journal of Science and Technology, 9(46).

Simon, P. A., Fielding, J. E. (2006). Public Health and Business: Partnership that Makes Cents. Health Affairs.

Talib, F., Rahman, Z., Akhtar, A. (2012). An Instrument for Measuring the Key Practices of Total Quality Management in ICT Industry. Service Business, and International Journal.

Westcott, R. T. (2013). The Certified Manager of Quality/Organizational Excellence Handbook. Wisconsin: ASQ Quality Press.

Wood, J. C., Wood, M. C. (2005). Joseph M. Juran: Critical Evaluation in Business and Management. Routledge.

Zaim, S., Bayyurt, N., Turkyilmaz, A., Solakoglu, N., Zaim, H. (2011). Measuring and Evaluating Efficiency of Hospitals Trough Total Quality Management. Journal of Transnational Management, Vol. 20. 